\section{The Burden of Proof}

SIR,-The creationists writing in defence of their beliefs are on the wrong tack; no one disputes their right to any theory whatever. What most biologists of my acquaintance abhor are the recent steps three American states have taken to interfere with biology teaching. California, for example, now includes in its guidelines to publishers of school and college texts a statement ("some of the scientific data may be best explained by a creation theory") with which few biologists agree.

The conscientious and informed teacher will ride the blow easily. It is, after all, good teaching if alternative ideas on the origin of species are briefly discussed and rationally dismissed. The teacher should be relating evidence to theory rather than handing out facts. What is unfortunate is that some teachers may be affected by the legisla. tion and will not appreciate the weighting that a specialist in evolution would accord conflicting theories. Modern disciplines depend on the establishment of books, individuals and schools as "authorities". Once such an authority has been set up it is reasonable that conflicting theories gather their evidence and appear as challengers. The workers in the field will then judge the evidence and predictions of the competing ideas. Evolution itself has appeared as a challenger and passed the test while creationism has been demoted; defeated challengers are entitled to retain their views and to search for new evidence but not to pretend to authority. The burden of proof rests with the creationists.

A number of creationists ${ }^{1-3}$ have written vaguely of "flaws" and "unanswered questions" in evolutionary thought. Such as? Even if there are any, this alone is not enough: creationism must be seen to be a better fit to the data. Only two arguments have been specifically mentioned. One is novel ${ }^{4}$, albeit facetious. This cites some recent attempts ${ }^{5}$ to quantify the role of genetic drift in evolution. Apart from the fact that this role is still contentious itself, evolution by drift is still evolution and not creation. Several creationists try to explain away the fossil record by postulating a succession of creations $\mathrm{s}^{3,6,7}$. This raises a multitude of unanswered questions. How many creations? How often? Why a plurality? Why so many clearly marked trends in fossil series? and so on.

Why do many of Nature's correspondents accept the Bible as the ultimate "authority" for the creation theory? This is not only poor biology but poor creationism too, for any archaeologist, theologist or philosopher could tell them that many of the stories in the Bible are copied from the folk-tales of long-ago tribes more ancient than the Hebrews ${ }^{8}$.

Yours faithfully,

$$
\text { J. P. A. Angseesing }
$$

Saint Paul's College,

Cheltenham GL50 4AZ

1 Van Kley, H., Nature, 240, 265 (1972).

2 Allbrook, D., Nature, 241, 150 (1973).

3 Hayward, A. T. J., Nature, 240, 577 (1972).

4 Harkins, R. N., Stenzel, P., and Black, J. A., Nature, 241, 226 (1973).

5 Haigh, J., and Smith, J. M., Genet. Res., 19, 73 (1972).

6 Lucas, E. C., Nature, 240, 366 (1972).

7 Fairbairn, J. W., Nature, 241, 225 (1973).

8 Cleator, P. E., Lost Languages (New American Library, 1962).

\section{Environmental Education}

SIR,-This Institution is now carrying out a survey of current and anticipated provisions at establishments of higher and further education and at schools in the field of education in environmental subjects. A substantial proportion of these establishments have already replied and the information supplied is now being analysed.

May I approach, through the courtesy of your columns, those interested in "environmental education" at various levels to submit private communications of relevance. The aim of this particular exercise is to sample intelligent public opinion outside the official institutions.

$$
\text { Yours faithfully, }
$$

\section{J. ROSE}

The Institution of Environmental

Sciences,

14 Princes Gate,

Hyde Park, London SW7 1PU

\section{In Defence of Dingle}

SIR,-Well, physics can now rest easy, in the assurance that it has been saved from heresy. Not one, but two occasions have been found in Nature to put down Professor Dingle (Nature, 239. $242 ; 1972$; and 241, 143; 1973). If people really thought that Dingle's work did not deserve serious thought and discussion, would it not have been better to ignore it completely?

When Dingle has failed to get a hearing, and his opponents seem to agree on little except the fact that they are opponents, it would be of little use for me to say anything on the matter as a piece of physics. But there are two or three general comments, which anyone might make, and which someone should make.

In the first place, Dingle was once recognized to be an authority in this matter. If he has now come to different conclusions, either there are good reasons for these second thoughts, or else they are to be put down as a foible of old age. But the writing is certainly not that of a senile man.

In the second place, it would appear that none of his critics has faced Dingle's points that $(a)$ he was discussing physics, not mathematics; and $(b)$ that all of the alleged experimental verifications involve circular arguments in their interpretation.

In the third place, if it should turn out that there is some truth in Dingle's views, the way in which they seem to have been brushed aside will not be likely to make science stand any higher in the public esteem. In the United States, especially, the "Velikovsky affair" left a bad taste in many mouths; it is surely not wise to seem to persecute another man, and one whose views are by no means so unorthodox.

$$
\begin{aligned}
& \text { Yours faithfully, } \\
& \text { H. L. ARMSTRONG }
\end{aligned}
$$

\section{Addendum}

IN the article "The First Fossil Record of Caecilian Amphibians" by R. Estes and M. H. Wake (Nature, 239, 228; 1972) the identification for Fig. $1 k-o$ was omitted from the figure legend. It should read: k-o, Geotrypetes seraphinii, MVZ 98253.

\section{Announcements \\ International Meetings}

March 22, 13th International Technical Scientific Meeting on Space (Secretariat, Via Cresecenzio n.9, 00193 Roma).

March 26-30, Annual Chemical Congress (Dr J. F. Gibson, The Chemical Society, Burlington House, London W1).

March 27-29, Ultrasonic Conference and Exhibition (Ultrasonic International '73. IPC Science and Technology Press Ltd, IPC House, 32 High Street, Guildford, Surrey).

March 27-29, PowTech International Powder Technology and Bulk Solids Exhibition and Conference (Specialist Exhibitions Ltd, Green Dragon House, 64 High Street, Croydon, Surrey).

March 27-29, The Practical Implications of Fracture Mechanisms (Meetings Secretary, The Institution of Metallurgists, Northway House, London N20).

March 28, Corrosion and Deterioration of Metals and Alternative Engineering Materials (Assistant Secretary, 14 Belgrave Square, London SW1). 